\title{
Uji Daya Hambat Ekstrak Etanol Batang Tumbuhan Saluang Belum Terhadap Bakteri Staphylococcus aureus
}

\author{
Nurul Qamariah ${ }^{1}$, Rezqi Handayani ${ }^{2}$, Andika Friskila ${ }^{3}$ \\ ${ }^{1,2,3}$ D-III Farmasi, Fakultas IImu Kesehatan, Palangka Raya, Kalimantan Tengah \\ e-mail : enqiyu9@gmail.com
}

\begin{abstract}
ABSTRAK
Salah satu tumbuhan obat yang digunakan oleh masyarakat Kabupaten Katingan Provinsi Kalimantan Tengah adalah Batang Tumbuhan Saluang Belum, secara empiris batang tumbuhan saluang belum digunakan sebagai afrodisiaka yang dapat meningkatkan stamina, gairah seksual dan kesuburan pria, dan sebagai antioksidan. Tujuan dari penelitian ini adalah mengetahui kemampuan daya hambat dan mengetahui pada konsentrasi berapa ekstrak etanol Batang Tumbuhan Saluang Belum mampu menghambat pertumbuhan bakteri Staphylacoccus aureus. Penelitian ini menggunakan metode eksperimen dengan pendekatan laboratorium yang akan dilakukan serangkaian percobaan. Hasil dari zona hambat ekstrak etanol batang saluang belum pada konsentrasi $0,5 \%$ adalah $26,7 \pm 2,76 \mathrm{~mm}$, pada konsentrasi $1 \%$ adalah $21,6 \pm 2,20 \mathrm{~mm}$, pada konsentrasi $5 \%$ adalah $20,5 \pm 0,90 \mathrm{~mm}$, pada konsentrasi $10 \%$ adalah $21,2 \pm 1,11 \mathrm{~mm}$, pada konsenstrasi $15 \%$ adalah $23,2 \pm 0,23 \mathrm{~mm}$, dan pada konsentasi $20 \%$ adalah 25,5 $\pm 0,36 \mathrm{~mm}$. Simpulan dari penelitian ini adalah MIC (Minimum Inhibitory Concentration) yang didapatkan adalah pada konsentrasi $0,5 \%$ ekstrak etanol Batang Saluang Belum mampu menghambat bakteri Staphylococcus aureus.
\end{abstract}

Kata Kunci : Saluang Belum, Uji Daya Hambat, Staphylococcus aureus.

\begin{abstract}
One of the medicinal plants used by the people of Katingan Regency, Central Kalimantan Province is the Saluang Belum stem, which empirically used as an aphrodisiac to increase stamina, sexual and fertility of male, and as an antioxidant. The purpose of this study was to find out the inhibition and to know which concentration of ethanol extract of Saluang Belum stem which had been able to inhibit the growth of Staphylococcus aureus bacteria. This research uses an experimental method with a laboratory approach. The results of the inhibitory zone of ethanol extract of Saluang Belum stem at a concentration of $0.5 \%$ was $26.7 \pm$ $2.76 \mathrm{~mm}$, at a concentration of $1 \%$ was $21.6 \pm 2.20 \mathrm{~mm}$, at a concentration of $5 \%$ was $20.5 \pm 0,90 \mathrm{~mm}$, at $10 \%$ concentration was $21.2 \pm 1.11 \mathrm{~mm}$, at $15 \%$ concentration was $23.2 \pm 0.23 \mathrm{~mm}$, and at $20 \%$ concentration was $25.5 \pm 0.36 \mathrm{~mm}$. Conclusions from this study were that the MIC (Minimum Inhibitory Concentration) obtained at $0.5 \%$ concentration of ethanol extract Batang Saluang Belum was able to inhibit the Staphylococcus aureus bacteria.
\end{abstract}

Keywords: Saluang Belum, Inhibitory Test, Staphylococcus aureus.

\section{PENDAHULUAN}

Menurut Undang-Undang Republik Indonesia Nomor 36 Tahun 2009 tentang kesehatan, pengertian obat tradisional ialah merupakan bahan atau ramuan yang berupa bahan tumbuhan, bahan hewan, bahan mineral, sediaan sarian (galenik) atau campuran dari bahan tersebut secara 
umum turun menurun telah digunakan untuk pengobatan dan dapat diterapkan sesuai dengan norma yang berlaku di masyarakat .

Kalimantan merupakan pulau di Indonesia yang terkenal dengan kekayaan keanekaragaman hayatinya.Tak hanya itu, kekayaan pengetahuan pengobatan tradisional dengan menggunakan tumbuhan yang diwariskan secara lisan dari generasi ke generasi pada etnis asli di Kalimantan juga sangat banyak.Etnis di Kalimantan memanfaatkan berbagai jenis tumbuhan untuk pengobatan tradisional dengan mengandalkan dari habitat alaminya.Sangat jarang Tumbuhan Hutan Berkhasiat Obat (THBO) ditanam secara khusus untuk dibudidayakan. Selain mereka belum terbiasa dengan kegiatan budidaya THBO, terdapat kepercayaan yang mereka yakini bahwa THBO yang dibudidayakan tidak memiliki khasiat sebaik yang diambil secara langsung dari alam, karena itu hutan merupakan gudang herbal bagi etnis asli di Kalimantan[2].

Penggunaan obat tradisional secara luas oleh masyarakat disebabkan selain karena alami, mudah didapat, harganya murah, serta penggunaan obat ramuan tumbuhan secara tradisional ini meminimalisir terjadinya efek samping yang ditimbulkan seperti yang sering terjadi pada pengobatan secara kimiawi, selain itu masih banyak orang yang beranggapan bahwa penggunaan obat tradisional lebih aman dibandingkan dengan obat sintesis[3].

Salah satu tumbuhan obat yang memiliki manfaat sebagai obat tradisional dan digunakan oleh masyarakat Kabupaten Katingan Provinsi Kalimantan Tengah adalah Batang Tumbuhan Saluang Belum, secara empiris batang tumbuhan saluang belum digunakan sebagai afrodisiaka yang dapat meningkatkan stamina, gairah seksual dan kesuburan pria, dan sebagai obat awet muda. Penggunaan batang tumbuhan saluang belum sebagai obat tradisional didasarkan pada pengalaman masyarakat secara turun menurun dan belum ada bukti ilmiah mengenai khasiat tumbuhan tersebut.Penggunaannya masih bersifat sederhana yaitu dengan merebus batang tumbuhan saluang belum dan yang kemudian air rebusannya diminum dan dipercaya masyarakat sebagai obat tradisional.Maka dari itu, penelitian ini mengangkat khasiat Batang Tumbuhan Saluang Belum sebagai antibakteri.

\section{METODOLOGI}

Penelitian ini menggunakan metode eksperimen atau percobaan (experiment research) dengan pendekatan laboratorium yang akan dilakukan serangkaian percobaan. Alat yang digunakan adalah neraca analitik, perkolator, alumunium foil, tali, corong, cawan porselin, beaker glass, gelas ukur, erlenmeyer, labu ukur, cawan petri, tabung 
reaksi, rak tabung reaksi, pipet ukur, ball pipet, ose, pinset, kapas lidi steril, kasa steril, batang pengaduk, kaca arloji, jangka sorong, Laminar Air Flow (LAF), evaporator, waterbath, autoklaf, inkubator, oven, desikator, hot plate, bunsen, korek api, plastik wrap, dan kertas label. Sedangkan bahan yang digunakan adalah ekstrak etanol Batang Tumbuhan Saluang Belum dengan konsentrasi $0,5 \%, 1 \%, 5 \%$, $10 \%, \quad 15 \%$ dan 20\%, bakteri Staphylococcus aureus, etanol 96\%, media Brain Heart Infusion (BHI), media Blood Agar Plate (BAP), media Mueller Hinton Agar (MHA), $\mathrm{NaCl} 0,9 \%$ steril, kertas cakram (paper disc), antibiotik Clindamycin 300 mg, dan standar Mc Farland 0,5.

\section{Pemilihan dan Pengambilan Simplisia}

Batang tumbuhan Saluang Belum yang dipilih untuk digunakan pada penelitian ini adalah Batang Tumbuhan Saluang Belum yang tumbuh di Kabupaten Katingan Kalimantan Tengah.

\section{Pengambilan}

\section{Bakteri}

\section{Staphylococcus aureus}

Staphylococcus aureus yang digunakan dalam penelitian ini yaitu bakteri dari Laboratorium Fakultas IImu Kesehatan Universitas Muhammadiyah Palangkaraya.

\section{Pembuatan Simplisia Batang \\ Tumbuhan Saluang Belum[4].}

Proses pembuatan simplisia Batang tumbuhan Saluang Belum diawali dengan pengumpulan bahan baku berupa Batang Tumbuhan Saluang Belum kemudian dilakukan sortasi basah dengan cara dicuci dengan air mengalir, setelah itu dilakukan perubahan bentuk batang dengan cara dirajang. Kemudian dikeringkan dengan cara menganginanginkan simplisia hingga kering, setelah kering simplisia kemudian disortasi kering. Batang yang telah kering kemudian di blender hingga halus dan diayak dengan menggunakan ayakan nomor 40 agar lebih memudahkan saat digunakan dalam penelitian.

\section{Pembuatan Ekstrak Etanol Batang Tumbuhan Saluang Belum}

Menimbang simplisia Batang tumbuhan Saluang Belum sebanyak 450 gram, kemudian dimasukkan ke dalam alat perkolator yang sudah diberi kasa sedikit demi sedikit, Tambahkan pelarut etanol $96 \%$ hingga simplisia terendam dalam pelarut berada $2 \mathrm{~cm}$ di atas sampel, rendam selama $3 \times 24$ jam sambil dilakukan pengadukan dan setiap 24 jam dilakukan penyaringan, kemudian mengambil ekstrak cair yang didapat dan menguapkan menggunakan evaporator hingga kadar etanol berkurang setengah atau $\pm 50 \%$, menguapkan ekstrak hasil dari evaporator di atas waterbath menggunakan cawan porselin pada suhu 
$95^{\circ} \mathrm{C}$ hingga diperoleh ekstrak kental, menimbang ekstrak kental yang didapat dan menghitung rendemennya. Rendemen ekstrak kental yang didapat dihitung dengan menggunakan rumus:

$$
\text { Rendemen }=\frac{\text { Berat ekstrak kental }}{\text { berat simplisia }} \times 100 \%
$$

\section{Sterilisasi Alat dan Bahan}

Alat dan bahan yang perlu disterilkan seperti erlenmeyer, cawan petri, tabung reaksi, kapas lidi steril, dan pinset, dengan cara dimasukkan ke dalam oven selama 1 jam pada suhu $180 \circ \mathrm{C}$, sterilisasi media menggunakan autoklaf dengan suhu $121 \mathrm{C}$ selama 20 menit dan sterilisasi ose dilakukan dengan cara dipanaskan di atas bunsen.

\section{Pembuatan Media BHI (Brain Heart Infusion)}

Ditimbang sebanyak 0,74 gram $\mathrm{BHI}$ dan dilarutkan dalam $20 \mathrm{~mL}$ aquadest, dipanaskan diatas hot plate hingga larut dan homogen. Setelah media BHI larut dan homogen, media dipipet sebanyak 5 $\mathrm{mL}$ ke dalam tabung reaksi yang telah disediakan sebelumnya.Kemudian disterilkan selama 15 menit di autoklaf dengan tekanan udara 1 atm dan dengan suhu $121^{\circ} \mathrm{C}[5]$.

\section{Pembuatan Media BAP (Blood Agar Plate)}

Ditimbang sebanyak 2,4 gram BAP dan dimasukkan ke dalam erlenmeyer selanjutnya aquadest ditambahkan sebanyak $60 \mathrm{~mL}$, serta dipanaskan dengan penangas listrik sampai media larut sempurna. Kemudian media disterilisasi menggunakan autoklaf selama 15 menit pada suhu $121^{\circ} \mathrm{C}$. Sementara berlangsungnya proses sterilisasi media BAP, tahapan selanjutnya, darah dimasukkan pada erlenmeyer yang berisi glass pearl steril, kemudian digojok hingga darah lisis atau tidak nampak lagi benang fibratnya. Setelah media BAP steril dan darah lisis, maka dilakukan pencampuran keduanya dan media dituangkan pada cawan petri yang telah disterilkan.

\section{Pembuatan Media MHA (Mueller HintonAgar) \\ Ditimbang sebanyak 11,4 gram} Mueller HintonAgar dan dilarutkan dalam $330 \mathrm{~mL}$ aquadest, dipanaskan diatas hot plate, kemudian disterilkan selama 15 menit di autoklaf dengan tekanan udara 1 atm, suhu $121^{\circ} \mathrm{C}[6]$.

\section{Penanaman Bakteri Staphylococcus aureus}

Diambil satu mata ose bakteri Staphylococcus aureus dan ditanam pada media $\mathrm{BHI}$ dan diinkubasikan pada suhu 37ํㅡ selama 24 jam [Isolasi Bakteri

\section{Staphylococcus aureus}

Diambil satu mata ose bakteri Staphylococcus aureus pada media $\mathrm{BHI}$ yang telah diinkubasikan, kemudian di streak pada media BAP, diinkubasikan pada suhu $37^{\circ} \mathrm{C}$ selama 24 jam [5]. 


\section{Pembuatan Larutan Standar Mc Farland 0,5}

Dicampurkan 0,05 mL BaCl2 1\% dan 9,95 mL H2SO4 1\% di dalam tabung reaksi. Kemudian ditutup rapat supaya tidak terjadi penguapan dan larutan harus dikocok setiap akan digunakan untuk membandingkan suspensi bakteri [5].

\section{Pembuatan Suspensi}

Bakteri

\section{Staphylococcus aureus}

$\mathrm{NaCl} \quad 0,9 \%$ steril dimasukkan ke dalam tabung reaksi sebanyak $5 \mathrm{~mL}$. Koloni bakteri dari BAP disiapkan dan lampu spritus dinyalakan. Satu mata ose bakteri Staphylococcus aureus diambil dari media BAP kemudian dimasukkan ke dalam $\mathrm{NaCl} \quad 0,9 \%$ hingga diperoleh kekeruhan yang disesuaikan dengan standar kekeruhan Mc Farland 0,5. Jika kurang keruh, suspensi ditambahkan koloni, sedangkan jika terlalu keruh dilakukan penambahan $\mathrm{NaCl}$ 0,9\%.

\section{Pembuatan}

Kontrol

\section{PositifClindamycin $\mathbf{3 0 0} \mathbf{~ m g}$}

Digerus tablet Clindamycin $300 \mathrm{mg}$ hingga halus dan ditimbang sebanyak 5 gram, dimasukkan ke dalam labu ukur dan ditambahkan $25 \mathrm{~mL}$ aquadest, dikocok hingga homogen, yang dianggap sama dengan konsentrasi 20\%. Kemudian dilanjutkan dengan membuat konsentrasi berbeda-beda yaitu $0,5 \%, 1 \%, 5 \%, 10 \%$, $15 \%$ dan $20 \%$.

\section{Pembuatan Konsentrasi Ekstrak Batang Tumbuhan Saluang Belum}

Ditimbang ekstrak kental Batang Tumbuhan Saluang Belum sebanyak 5 gram dan dilarutkan dalam $25 \mathrm{~mL}$ pelarut etanol $96 \%$ yang dianggap sama dengan konsentrasi ekstrak 20\%. Kemudian membuat konsentrasi ekstrak Batang Tumbuhan Saluang Belum yang berbedabeda yaitu $0,5 \%, 1 \%, 5 \%, 10 \%, 15 \%$ dan $20 \%$.

\section{Uji Daya Hambat}

Setelah membuat suspensi bakteri Staphylococcus aureus yang telah disesuaikan dengan standar kekeruhan Mc Farland 0,5 kemudian di streak di media Mueller HintonAgar dengan menggunakan kapas lidi steril. Disc Clindamycin $300 \mathrm{mg}$ dan disk ekstrak Batang Tumbuhan Saluang Belum (Lavanga sarmentosa) ditanam sesuai dengan masing-masing konsentrasi yang sudah ditentukan.Kemudian dilakukan inkubasi pada suhu $37^{\circ}$ C selama 24 jam.Tahap selanjutnya ialah mengamati zona hambatan yang berupa daerah bening yang terbentuk di sekitar disc dan melakukan pengukuran terhadap diameter zona hambat yang terbentuk dengan menggunakan jangka sorong.

\section{Pengamatan}

a. Pengamatan Utama

Pengujian bakteri Staphylococcus aureus menggunakan metode difusi untuk menentukan aktivitas agen 
antimikroba.Metode ini dilakukan pada media Mueller HintonAgar.Aktivitas mikroba diuji dengan menggunakan penentuan MIC (Minimum Inhibitory Concentration).Minimum Inhibitory Concentration merupakan konsentrasi terendah yang masih mampu menghambat pertumbuhan organisme (Sacher et al., 2000).Agen antimikroba yang dipakai adalah ekstrak Tumbuhan Batang Saluang Belum dengan konsentrasi $0,5 \%, 1 \%, 5 \%, 10 \%, 15 \%$ dan $20 \%$. Pengamatan dilakukan dengan cara mengukur diameter dari daya hambat ekstrak Batang Tumbuhan Saluang Belum terhadap bakteri Staphylococcus aureus.

\section{b. Kontrol Positif Obat yang Dapat Menghambat Pertumbuhan Bakteri Staphylococcus aureus}

Menurut Peraturan Menteri Kesehatan Republik Indonesia (2011) [8]tentang tentang Pedoman Umum Penggunaan Antibiotik, Clindamycin menghambat sebagian besar kokus Gram-positif dan sebagian besar bakteri anaerob, tetapi tidak bisa menghambat bakteri Gramnegatif aerob seperti Haemophilus, Mycoplasma dan Chlamydia, salah satunya adalah bakteri Staphylococcus aureus. Konsentrasi Clyndamicin yang digunakan antara lain 0,5\%, 1\%, 5\%, 10\%, $15 \%$ dan $20 \%$.

\section{Pengolahan dan Analisa Data}

Teknik analisis data dalam penelitian ini menggunakan cara pengukuran diameter zona hambat ekstrak etanol BatangTumbuhan Saluang Belum terhadap bakteri Staphylococcus aureus pada cawan petri menggunakan jangka sorong dengan satuan milimeter $(\mathrm{mm})$. Hasil pengujian dengan cara pengukuran diameter zona hambat ekstrak etanol Batang Tumbuhan Saluang Belum terhadap bakteri Staphylococcus aureus menggunakan jangka sorong juga disajikan dalam bentuk tabel dan foto, serta hasil pengukuran zona hambat dibandingkan dengan klasifikasi respon hambatan ekstrak terhadap pertumbuhan bakteri dan standar CLSI.

Tabel 1.Standar CLSI (Clinical and Laboratory Standard Institute) [9].

\begin{tabular}{cccc}
\hline \multirow{2}{*}{$\begin{array}{c}\text { Antimicrobal } \\
\text { Agent }\end{array}$} & \multicolumn{3}{c}{ Test Cultures (zone diameters in mm) } \\
\cline { 2 - 4 } & Resistant & Intermediate & Susceptible \\
\hline Clindamycin & $\leq 14 \mathrm{~mm}$ & $15-20 \mathrm{~mm}$ & $\geq 21 \mathrm{~mm}$ \\
\hline
\end{tabular}

\section{HASIL DAN PEMBAHASAN}

Jumlah total ekstrak kental yang didapatkan adalah 16,3685 gram dan rendemen ekstrak yang diperoleh adalah
3,637\%. Organoleptis ekstrak kental batang Saluang Belum bertekstur kental, berwarna coklat kehitaman, dan tidak berbau.Hasil pengukuran zona hambat 
dibandingkan dengan standar CLSI Institute).

(Clinical and Laboratorary Standard

Tabel 2.Pengukuran Zona Hambat

\begin{tabular}{|c|c|c|c|c|c|c|}
\hline \multirow[b]{2}{*}{ Sampel Uji } & \multirow[b]{2}{*}{$\begin{array}{c}\text { Konsentrasi } \\
(\%)\end{array}$} & \multicolumn{3}{|c|}{ Zona Hambat (mm) } & \multirow{2}{*}{$\begin{array}{c}\text { Rata-rata } \\
\text { Zona Hambat } \\
\pm \text { SD } \\
(\mathrm{mm}) \\
\end{array}$} & \multirow[b]{2}{*}{$\begin{array}{l}\text { Interpretasi } \\
\text { daya hambat }\end{array}$} \\
\hline & & I & II & III & & \\
\hline \multirow{6}{*}{$\begin{array}{c}\text { Clindamycin } \\
(+)\end{array}$} & 0,5 & 43 & 43,5 & 43,2 & $22,2 \pm 0,29$ & Susceptible \\
\hline & 1 & 43,7 & 44,2 & 44,2 & $43,2 \pm 0,55$ & Susceptible \\
\hline & 5 & 45,3 & 46,9 & 46,2 & $44,2 \pm 0,81$ & Susceptible \\
\hline & 10 & 51 & 49,5 & 49,9 & $46,2 \pm 0,93$ & Susceptible \\
\hline & 15 & 53,1 & 53,1 & 52,8 & $49,9 \pm 0,58$ & Susceptible \\
\hline & 20 & 53,7 & 53,4 & 53,8 & $52,8 \pm 0,40$ & Susceptible \\
\hline \multirow{6}{*}{$\begin{array}{l}\text { Ekstrak } \\
\text { Batang } \\
\text { Tumbuhan } \\
\text { Saluang } \\
\text { Belum }\end{array}$} & 0,5 & 29,8 & 25,6 & 24,6 & $26,7 \pm 2,76$ & Susceptible \\
\hline & 1 & 20,5 & 20,1 & 24,1 & $21,6 \pm 2,20$ & Susceptible \\
\hline & 5 & 21 & 21,1 & 19,5 & $20,5 \pm 0,90$ & Intermediate \\
\hline & 10 & 20,2 & 22,4 & 21,1 & $21,2 \pm 1,11$ & Susceptible \\
\hline & 15 & 23,5 & 23,1 & 23,1 & $23,2 \pm 0,23$ & Susceptible \\
\hline & 20 & 25,1 & 25,6 & 25,8 & $25,5 \pm 0,36$ & Susceptible \\
\hline & & 8 & ata-1 & dari 3 & pengulangan & \\
\hline
\end{tabular}

Tumbuhan Saluang Belum merupakan tumbuhan yang mempunyai suatu khasiat yang dapat dimanfaatkan oleh masyarakat Kabupaten Katingan sebagai obat tradisional untuk menambah stamina dan antioksidan.Penelitian ini bertujuan untuk memperoleh informasi ilmiah mengenai tumbuhan Saluang Belum yang nantinya digunakan sebagai acuan dalam penelitian selanjutnya.

Sebelum diekstrak, batang Tumbuhan Saluang Belum dicuci dengan air bersih yang mengalir, tujuannya untuk menghilangkan pengotor yang melekat pada bahan simplisia. Kemudian Batang dirajang, tujuannya untuk memperluas permukaan agar mempermudah proses pengeringan. Setelah batang dirajang lalu batang dikeringkan dengan cara di anginanginkan. Pengeringan pada simplisia dimaksudkan untuk mengurangi kandungan air dalam bahan.Kandungan air yang tinggi dalam suautu bahan dapat mendorong terjadinya reaksi enzimatik yang mengakibatkan perubahanperubahan kimia.Perubahan komposisi kimia terutama pada senyawa-senyawa berkhasiat dapat menurunkan mutu simplisia yang dihasilkan, disamping itu kandungan air yang tinggi merupakan media bagi tumbuhnya mikroorganisme atau jamur yang dapat mencemari bahan.

Metode yang digunakan untuk memperoleh ekstrak Batang Tanaman Saluang Belum adalah metode perkolasi. Metode ini digunakan karena cara 
perkolasi mudah dan sederhana dilakukan, resiko serta peluang pengotor sangat kecil. Teknik pada metode ini menggunakan pelarut yang selalu baru sampai sempurna (exhaustive extraction) yang umumnya dilakukan pada temperatur ruangan.Pengamatan sederhana untuk mengindikasikannya yaitu dengan warna pelarut, dimana bila pelarut sudah tidak lagi berwarna (bening) menandakan metabolit sudah tersari. Pelarut yang digunakan pada proses ekstraksi ini adalah etanol $96 \%$, penggunaan etanol 96\% karena etanol bersifat universal yang dapat mengikat semua komponen kimia yang terdapat dalam serbuk simplisia baik yang bersifat polar, semi polar, maupun non polar [10].

Ekstrak cair yang telah diperoleh dari ekstraksi perkolasi akan dievaporasi menggunakan evaporator. Tujuan dievaporasi adalah untuk memekatkan konsentrasi larutan sehingga didapatkan larutan dengan konsentrasi yang tinggi. Prinsip evaporator adalah proses pemisahan ekstrak dari cairan penyarinya dengan pemanasan yang dipercepat oleh putaran labu, cairan penyari dapat menguap 5-10ㅇ dibawah titik didih pelarutnya, karena adanya penurunan tekanan sehingga zat yang terkandung didalam pelarut tidak rusak oleh suhu tinggi. Ekstrak cair Batang Tanaman Saluang Belum dievaporasi untuk memisahkan ekstrak dengan cairan penyarinya agar diperoleh ekstrak kental Batang Tanaman Saluang Belum.

Dalam penelitian ini dilakukan pengujian ekstrak etanol Batang Tanaman Saluang Belum sebagai penghambat pertumbuhan bakteri Staphylococcus aureus. Penelitian uji daya hambat antibakteri ekstrak etanol Batang Tanaman Saluang Belum terhadap pertumbuhan bakteri Staphylococcus aureus menggunakan media Mueller Hinton Agar dengan metode Kirby-Bauer yaitu metode difusi dengan disc. Pengujian ekstrak etanol Batang Tanaman Saluang Belum dibuat dengan enam konsentrasi yaitu $0,5 \%, 1 \%, 5 \%, 10 \%$, $15 \%$, 20\%, digunakannya konsentrasi tersebut karena pada pengujian ini menggunakan penentuan MIC (Minimum Inhibitory Concentration) yang merupakan konsentrasi terendah yang masih mampu menghambat pertumbuhan organisme. Hasil penelitian menunjukkan adanya daya hambat dari ekstrak etanol Batang Tanaman Saluang Belum terhadap pertumbuhan bakteri Staphylococcus aureus setelah proses inkubasi pada suhu $37^{\circ} \mathrm{C}$ menggunakan inkubator selama 24 jam. Kemampuan daya hambat ekstrak etanol Batang Tanaman Saluang Belum) terhadap bakteri uji yang ditandai dengan terbentuknya zona bening disekitar disc.

Berdasarkan hasil pengamatan pada ekstrak etanol Batang Tanaman Saluang Belum yang dilakukan sebanyak tiga kali pengulangan, menunjukkan diameter zona 
hambat yang terbentuk bervariasi. Ratarata hasil zona hambat ekstrak etanol Batang Kayu Saluang Belum pada konsentrasi $0,5 \%$ didapatkan hasil 26,7 $\mathrm{mm}$, pada konsentrasi $1 \%$ didapatkan hasil 21,6 mm, pada konsentrasi $5 \%$ didapatkan hasil 20,5 $\mathrm{mm}$, pada konsentrasi $10 \%$ didapatkan hasil 21,2 $\mathrm{mm}$, pada konsentrasi $15 \%$ didapatkan hasil 23,2 $\mathrm{mm}$, dan pada konsentrasi $20 \%$ didapatkan hasil 25,5 mm.

Pengujian penetapan potensi antibiotik secara mikrobiologi sebagai kontrol positif dengan perlakuan yang sama seperti ekstrak Batang Tanaman Saluang Belum menggunakan antibiotik Clindamycin $300 \mathrm{mg}$ dengan konsentrasi 0,5\%, $1 \%, 5 \%, 10 \%, 15 \%$, dan $20 \%$. Pada pengujian tersebut rata-rata zona hambat antibiotik Clindamycin pada konsentrasi 0,5\% didapatkan hasil $43,2 \mathrm{~mm}$, pada konsentrasi $1 \%$ didapatkan hasil 44,2 $\mathrm{mm}$, pada konsentrasi $5 \%$ didapatkan hasil 46,2 mm, pada konsentrasi $10 \%$ didapatkan hasil 49,9 $\mathrm{mm}$, pada konsentrasi 15\% didapatkan hasil 52,8 $\mathrm{mm}$, dan pada konsentrasi $20 \%$ didapatkan hasil 53,8 mm. Berdasarkan CLSI (Clinical Laboratory Standart Institute) hasil zona hambat antibiotik Clindamycin pada konsentrasi $0,5 \%, 1 \%$, $5 \%, \quad 10 \%$, $15 \%$, dan $20 \%$ dapat dikategorikan susceptible. Pengukuran zona hambat ini dilakukan dengan cara mengambil garis mendatar atau horizontal pada daerah bening di sekitar disc dengan menggunakan jangka sorong. Jika dibandingkan dengan kontrol positif yang memiliki perlakuan sama dengan konsentrasi ekstrak maka zona hambatan ekstrak Batang Tanaman Saluang Belum pada konsentrasi $0,5 \%$ dapat dikategorikan Susceptible, pada konsentrasi $1 \%$ dapat dikategorikan Susceptible, pada konsentrasi 5\% dapat dikategorikan Intermediate, pada konsentrasi $10 \%$ dapat dikategorikan Susceptible, pada konsentrasi 15\% dapat kategorikan Susceptible, dan pada konsentrasi $20 \%$ dapat dikategorikan Susceptible.

Saponin merupakan senyawa metabolit sekunder yang banyak dijumpai pada tumbuhan, mempunyai sifat seperti sabunatau deterjen, larut dalam air, lemak dan pelarut polar.Saponin memiliki efek antibakteri. Senyawa saponin dapat melakukan mekanisme penghambatan bakteri dengan cara membentuk senyawa kompleks dengan membran sel bakteri melalui ikatan hidrogen, sehingga dapat menghancurkan sifat permeabilitas dinding sel bakteri dan akhirnya dapat menimbulkan kematian sel pada bakteri[11].

Tanin merupakan senyawa aktif metabolit sekunder yang diketahui mempunyai beberapa khasiat yaitu sebagai astringen, anti diare, anti bakteri, dan antioksidan.Tanin merupakan komponen zat organik yang sangat kompleks, terdiri dari senyawa fenolik yang sukar dipisahkan dan sukar mengkristal, mengendapkan protein dari 
larutannya dan bersenyawa dengan protein tersebut [12].Tanin juga mempunyai daya antibakteri dengan cara mempresipitasi protein, karena diduga tanin mempunyai efek yang sama dengan senyawa fenolik. Efek antibakteri tanin antara lain: reaksi dengan membran sel, inaktivasi enzim, dan destruksi atau inaktivasi fungsi genetik, selain itu aktivitas antibakteri senyawa tanin adalah dengan cara mengkerutkan dinding sel atau membran sel, sehingga mengganggu permeabilitas sel itu sendiri. Akibat terganggunya permeabilitas, sel tidak dapat melakukan aktivitas hidup sehingga pertumbuhannya terhambat atau bahkan mati [11].

Berdasarkan hasil pengukuran zona hambat pada ekstrak etanol batang tanaman saluang belum pada konsentrasi 0,5\%, pada konsentrasi tersebut ekstrak etanol Batang Tanaman Saluang Belum sudah mampu menghambat bakteri Staphylococcus aureus. Konsentrasi efektif merupakan konsentrasi terkecil yang memiliki daya hambat besar, maka dengan adanya daya hambat yang besar menunjukkan kepekaan mikroorganisme terhadap antibakteri[13]. Seharusnya, semakin tinggi konsentrasi ekstrak yang diberikan, maka semakin besar aktivitas penghambatannya.Pada umumnya diameter zona hambat cenderung meningkat sebanding dengan meningkatnya konsenstrasi ekstrak.Dalam penelitian ini terdapat penurunan zona hambat pada konsentrasi 5\%.Diameter zona hambat tidak selalu naik sebanding dengan naiknya konsentrasi antibakteri, ini terjadi karena perbedaan kecepatan difusi senyawa antibakteri pada konsentrasi senyawa antibakteri yang berbeda juga memberikan diameter zona hambat yang berbeda pula[14]. Terbentuknya zona hambat disekitar disc menunjukkan adanya aktivitas senyawa antibakteri terhadap bakteri uji yaitu Staphylococcus aureus, semakin besar zona hambat yang terbentuk semakin banyak bakteri yang mati, dapat dilihat dari daerah bening yang ada disekitar disc.

Staphylococcus aureus merupakan mikroflora normal manusia.Bakteri ini biasanya terdapat pada saluran pernapasan atas dan kulit.Keberadaan Staphylococcus aureus pada saluran pernapasan atas dan kulit pada individu jarang menyebabkan penyakit, individu sehat biasanya hanya berperan sebagai karier. Infeksi serius akan terjadi ketika resistensi inang melemah karena adanya perubahan hormon, adanya penyakit, luka, atau perlakuan menggunakan steroid atau obat lain yang memengaruhi imunitas sehingga terjadi pelemahan inang[15].

Penggunaan antibiotik Clindamycin sebagai kontrol positif dikarenakan Menurut Peraturan Menteri Kesehatan Republik Indonesia[8] tentang Pedoman Umum Penggunaan Antibiotik, Clindamycin menghambat sebagian besar kokus Gram-positif dan sebagian besar 
bakteri anaerob, tetapi tidak bisa menghambat bakteri Gram-negatif aerob seperti Haemophilus, Mycoplasma dan Chlamydia, seperti Staphylococcus aureus.

Penggunaan Batang Tanaman
Saluang Belum secara tradisional
digunakan oleh masyarakat sebagai penambah stamina pada pria dan sebagai antioksidan saja, tetapi dari hasil penelitian tentang Uji daya Hambat Ekstrak Etanol Batang Tanaman Saluang Belum, yang menunjukkan kemampuan daya hambat yang dimiliki oleh ekstrak Batang Tanaman Saluang Belum terhadap Staphylococcus aureus juga sebagai antibakteri. Dengan penelitian ini diharapkan dapat menjadi pengetahuan masyarakat tentang manfaat ekstrak kayu Saluang Belum sebagai antibiotik, mengingat masyarakat pada zaman sekarang ini lebih mengarah untuk kembali ke alam (Back to nature) maka ekstrak kayu Saluang Belum dapat digunakan sebagai obat tradisional alami oleh masyarakat khususnya sebagai antibakteri yang disebabkan oleh Staphylococcus aureus.

\section{KESIMPULAN}

Dari penelitan yang telah dilakukan dapat disimpulkan:

1. Ekstrak etanol Batang Tanaman Saluang Belum mampu menghambat pertumbuhan bakteri Staphylococcus aureus.
2. Pada konsentrasi $0,5 \%, 1 \%, 5 \%, 10 \%$, $15 \%$, dan 20\% ekstrak etanol Batang Tanaman Saluang Belum mampu menghambat pertumbuhan bakteri Staphylococcus aureus

\section{DAFTAR PUSTAKA}

1. Departemen Kesehatan Republik Indonesia. 2009. Undang-undang Republik Indonesia Nomor 36 Tahun 2009 tentang Kesehatan. Jakarta.

2. Handayani, R., Fahruni, dan Novaryatiin, S. 2016. "Potensi Tumbuhan Kelakai (Stenochlaena palustris (Burm. f.) Bedd.) Sebagai Afrodisiaka". Laporan Penelitian Dosen Pemula Universitas Muhammadiyah Palangkaraya: Palangkaraya.

3. Rusmita, H. 2017. 'Uji Daya Hambat Ekstrak Etanol Akar Kelakai (Stenochlaena palustris(Burm. f.) Bedd.) Terhadap Bakteri Escherichia coli". Palangka Raya: KTI Universitas Muhammadiyah Palangkaraya.

4. Departemen Kesehatan Republik Indonesia. 1995. Materia Medika Indonesia Jilid IV : Jakarta.

5. Pakekong, E.D., Homenta, H., Mintjelungan, C.N. 2016. "Uji Daya Hambat Ekstrak Bawang Bombay (Allium cepa L) Terhadap Pertumbuhan Bakteri Staphylococcus aureus Secara In Vitro". Manado: Jurnal IImiah Farmasi Universitas Sam Ratulangi. 2016 1(5): 2302-2493.

6. Ramadanti. 2008. Pembuatan MHA (Mueller Hinton Agar). Lampung :Skripsi Fakultas Kedokteran Universitas Lampung.

7. Sacher, R. A., McPherson, R. A., Campos, J, M., \& Widmann, F. K. 2000. Widmann's Clinical Interpretation Of Laboratory Test. FA Davis.

8. Departemen Kesehatan Republik Indonesia. 2011. Peraturan Menteri Kesehatan Republik Indonesia Nomor 2406 Tahun 2011Tentang Pedoman Penggunaan Antibiotik. Jakarta.

9. Clinical Laboratory Standart Institute. 2016. Performance Standart For 
Antimicrobial Susceptibility Testing; Twentieth Information Supplement. USA.

10. Istiqomah. 2013. "Perbandingan Metode Ekstraksi Maserasi dan Sokletasi terhadap Kadar Piperin Buah Cabe Jawa (Piperis Retrofracti Frustus)". Skripsi: Jakarta.

11. Khunaifi, M. 2010. "Uji Aktifitas Antibakteri Ekstrak Daun Binahong (Anredera cordifolia (Ten) Steenis Terhadap akteri Staphyilococcus aureus dan Pseudomonas aeruginosa)". Skripsi Universitas Islam Negeri Maulana Malik Ibrahim: Malang.

12. Desmiaty, Y., Ratih H., Dewi, M.A., dan Agustin, R. 2008. "Penentuan Jumlah Tanin Total pada Daun Jati Belanda (Guazuma ulmifolia Lamk) dan Daun Sambang Darah (Excoecaria bicolor Hassk.) Secara Kolorimetri dengan Pereaksi Biru Prusia”. Jurnal: Ortocarpus. 2008 2(8): 106-109.

13. Purwoko, Tjahjadi. 2007. Fisiologi Mikroba. Bumi Askara : Jakarta.

14. Elifah, E. 2010 'Uji Antibakteri Fraksi Aktif Ekstrak Metanol Daun Senggani (Melastoma candidum, D.Don) Terhadap Escherichia coli dan Bacillussubtilis Serta Profil Kromatografi Lapis Tipis'. Skripsi. FMIPA UNS : Surakarta

15. Munif. 2009. Escherichia coli Disekitar Air Minum Kita. Institut Pertanian : Bogor. 